\title{
Investigation of Social Science Pre-Service Teachers' Readiness to the Use of Podcast as A Learning Tool
}

\author{
Olusola Adedoja ${ }^{1}$, Christopher Omotunde ${ }^{2}$ \\ ${ }^{1}$ Department of Teacher Education, University of Ibadan, Nigeria \\ ${ }^{2}$ Department of Educational Technology, Adeyemi College of Education, Ondo, Nigeria
}

\begin{abstract}
The study described the influence of age, gender and teaching subject on the readiness of students to the use of podcasting as a learning tool in the classroom. The sample comprises a total of 240 pre-service teachers in the faculty of Education, 100 level students offering TEE 141 (Social Studies Methods). There are 2 research questions and 3 hypotheses: What technological gadget do pre-service teachers have to interact with podcast? Are social science pre service teachers ready for the use of podcasting? There is no significant difference in the readiness of podcasting use between male and female pre-service teachers. There is no significant difference in the readiness of podcasting use based on age levels of social science pre-service teachers. There is no significant difference in the readiness of podcasting use based on social science preservice teachers' teaching subjects. The hypotheses were tested at 0.05 level of significance. The instrument used in the collection of data is the Podcast Readiness Questionnaire (PRQ). The reliability coefficient was derived from Kuder-Richardson (KR 20) formula and its value was .94. The result of the study was analyzed using the descriptive statistics, student T-test and analysis of variance (ANOVA). The findings revealed that there is no significant difference in the level of readiness of pre-service teachers based on age, gender and teaching subjects. It further reveals that the pre-service teachers are fully ready for the use of podcasting because they feel it will help them to revise for examinations, revise lectures and help their learning while being mobile.
\end{abstract}

Keywords: Learning Tool, Podcasting, Pre-Service Teachers, Readiness.

\section{Introduction}

The development of the Internet has created new ways for educators to communicate with learners. Many Higher-Education institutions have adopted the use of virtual learning environments and incorporate elearning into their traditional teaching as part of a blended-learning approach. Compared with traditional lectures, e-learning has the advantage of allowing learners to choose when, where, and how they study. It also allows learners to review material and gain feedback (Evans \& Fan, 2002).

The term e-learning is a general term for many concepts and definitions of Web-based learning, distance learning, online learning, and learning using electronic devices. However, much of e-learning has turned mobile. Mobile learning is described as "Learning that happens across locations, or that takes advantage of learning opportunities offered by portable technologies." This is expanded, where the focus is on the technology (which could be in a fixed location, such as a classroom); learning across contexts, where the focus is on the mobility of the learner, interacting with portable or fixed technology; and learning in a mobile society, with a focus on how society and its institutions can accommodate and support the learning of an increasingly mobile population.

Mobile learning (m-learning) inherits these advantages from e-learning, but extends their reach by making use of portable (handheld) wireless technologies. Suitable devices include digital media players (e.g. iPods, MP3 players), smartphones (e.g. Blackberry, iPhone), and Personal Digital Assistants or PDAs (e.g. Palm, Pocket PC).

Modern learners have increasing demands on their time and are often forced to study in their lunch breaks, in the evenings and at weekends; and to study at work or on the bus, or in the car. The use of portable technologies makes it easier for learners to study when and where they want by making it simple for them to transport their learning materials. They also facilitate "just-in-time" learning where learners can often take advantage of unexpected free time since they frequently have their devices with them. The ability to study whilst travelling on transport uniquely distinguishes m-learning from e-learning, since (with the possible exception of the more cumbersome laptop) the latter normally requires access to a desktop computer and wired Internet access. (Evans 2007).

Podcasting is a form of m-learning and one of the rapidly growing methods of delivering content online. It is a method of distributing audio content via the Internet, allowing users to subscribe to a feed of files (Walton et al. 2005). Podcast is the transportation of audio files from computer to Mp3 player so that it can be heard by the listener on demand. It is the automatic delivery of audio or visual content over a network via free 
subscription (apple.com). Though content may be made available by direct download or streaming, the "ease of publication, ease of subscription via Really Simple Syndication (RSS) enclosures, and ease of use across multiple environments" has distinguished podcast from other digital-media formats (Campbell 2005). Podcast has a growth in broadband Internet access, access to multimedia capable personal computers, and the adoption of portable media players (i.e., MP3 players, music-capable mobile phones and PDAs) (Udell 2005).

For educational institutions, podcasting provides educators with an opportunity to "meet today's students where they live - on the Internet and on audio players (EDUCAUSE 2005)." Classroom material and leisure-time entertainment come through the same medium and desktop utility, thus, intertwining a student's educational experience with other aspects of his/her life (Campbell 2005). By combining podcasting with the widespread popularity of portable media players, a vision of anytime and anyplace education, i.e., mobile learning will soon be realized (Chan \& Lee 2005).

\section{Statement of Problem}

In education, there has been an exponential technological change and this has enormous implications on the teaching learning process. Several technologies such as mobile phones, $\mathrm{mp} 3$, digital cameras, blogs, wiki, video games, podcasting and many more which have a strong potential in education are not readily used in many schools. In general, students are learning, adopting, and using technology at a much more rapid pace than their teachers (Marc Prensky 2007). By this divide, growing larger every day, there are strategies for teaching with technology that can make both students and teachers comfortable, while allowing the students to go as far as they can with the technologies that characterize their age and that they love to use. Also, bearing the large classroom that characterizes our institutions and the different learning styles of students, there is the need to develop an effective and efficient learning strategy that will help in keeping up with advances in technical innovations for education, and also improve the learning situation. However, timely research needs to be performed to reveal outcomes that can help bridge these gaps.

It is in the light of this, that this study investigated the readiness of social science pre-service teachers to the use of podcast as a learning tool.

\section{Research Questions}

1. What technological gadget do pre-service teachers have to interact with podcast

2. Are social science pre service teachers ready for the use of podcasting

\section{Hypotheses}

1. There is no significant difference in the level of readiness for podcasting between male and female social science pre-service teachers

2. There is no significant difference in the level of readiness for podcasting based on age levels of social science pre-service teachers

3. There is no significant difference in the level of readiness for podcasting based on social science preservice teachers' teaching subjects

\section{Methodology}

Quantitative methodological approach and descriptive statistics were adopted for this study. Two hundred and forty 100 level social science pre-service teachers of the Faculty of Education of the University of Ibadan participated in the study. The faculty consists of six departments namely Teacher Education (TEE), Adult Education (ADE), Special Education (SPE), Kinetics and Human Education (KHE), Guidance \& Counseling Education (GCE), Educational Management (EME). The pre-service teachers offers various teaching subjects which includes, Economics, Geography, Political Science, Religious Studies, History.

\section{Research Instrument And Data Analysis}

The research instrument used for this study was Podcast Readiness Questionnaire (PRQ). Data collected was analyzed using descriptive statistics such as frequencies, Students' T-test and analysis of variance (ANOVA)

\section{Result And Discussion Of Finding}

A total of 240 surveys were distributed to social science pre-service teachers. All the participants responded, resulting in a $100 \%$ response rate. A description of the demographic and teaching subject characteristics of respondents is provided in Table la-c. 
Table 1a

Gender

\begin{tabular}{|c|c|c|c|c|c|}
\hline & & Frequency & Percent & Valid Percent & $\begin{array}{c}\text { Cumulative } \\
\text { Percent }\end{array}$ \\
\hline \multirow[t]{3}{*}{ Valid } & Male & 105 & 43.8 & 43.8 & 43.8 \\
\hline & Female & 135 & 56.3 & 56.3 & 100.0 \\
\hline & Total & 240 & 100.0 & 100.0 & \\
\hline
\end{tabular}

Table 1a shows that $56.3 \%$ of the participants are female while $43.8 \%$ are male.

Table 1b

\begin{tabular}{|c|c|c|c|c|c|}
\hline \multicolumn{6}{|c|}{ Age } \\
\hline & & Frequency & Percent & Valid Percent & $\begin{array}{c}\text { Cumulative } \\
\text { Percent }\end{array}$ \\
\hline \multirow[t]{5}{*}{ Valid } & $15-20$ years & 86 & 35.8 & 35.8 & 35.8 \\
\hline & $21-25$ years & 113 & 47.1 & 47.1 & 82.9 \\
\hline & $26-30$ years & 30 & 12.5 & 12.5 & 95.4 \\
\hline & 31-above y ears & 11 & 4.6 & 4.6 & 100.0 \\
\hline & Total & 240 & 100.0 & 100.0 & \\
\hline
\end{tabular}

Table $1 \mathrm{~b}$ indicates that $47.1 \%$ of the 240 participants that took part in the study were between $21-25$ years old, while $35.8 \%$ were between $15-20$ years old, $12.5 \%$ are between $26-30$ years old and $4.6 \%$ are between 31 and above.

Table 1c

Teaching Subject

\begin{tabular}{|ll|r|r|r|r|}
\hline & & & & Cumulative \\
& & Frequency & Percent & Valid Percent & Percent \\
\hline Valid & ECO & 78 & 32.5 & 32.5 & 32.5 \\
& 19 & 7.9 & 7.9 & 40.4 \\
GEO & 122 & 50.8 & 50.8 & 91.3 \\
POS & 12 & 5.0 & 5.0 & 96.3 \\
RES & 2 & .8 & .8 & 97.1 \\
HISTORY & 7 & 2.9 & 2.9 & 100.0 \\
OTHERS & 240 & 100.0 & 100.0 & \\
Total & 19 & \\
\hline
\end{tabular}

In table $1 \mathrm{c}$, it shows a wide distribution in terms of their teaching subjects. A half of the participants $50.8 \%$ offers POS but the remaining participants were distributed across other teaching subjects $(32.5 \%$ ECO, 7.9\% GEO, 5.0\% RES, 0.8\% HISTORY, 2.9\% OTHERS).

\section{Research Question 1}

\section{Research Question}

What technological gadget do pre-service teachers have to interact with podcast?

Table 2: frequency and percentage of podcast communication facilities

\begin{tabular}{|l|l|l|}
\hline Communication Facilities & Frequency & $\%$ \\
\hline Mobile Phone & 215 & 89.6 \\
\hline PDA & 5 & 2.1 \\
\hline Mp3 & 11 & 4.6 \\
\hline IPod & 4 & 1.7 \\
\hline Personal Computer (PC) & 3 & 1.3 \\
\hline No Response & 2 & 0.8 \\
\hline Total & 240 & 100 \\
\hline
\end{tabular}


Table 2 shows the responses of the social science pre-service teachers to the technological gadget they have for podcasting operation. $89.6 \%$ of the respondent has mobile phones, while $2.1 \%$ possess PDA. 4.6\% have Mp3, 1.7\% is with IPod and 1.3\% had personal computer. It is deduced from the table that mobile phones are the most available technological gadget for podcasting among the pre-service teachers.

\section{Research Question 2}

Are social science pre-service teachers ready for the use of podcasting?

Table 3: frequency and percentage of level of readiness of pre-service teachers for podcasting.

\begin{tabular}{|l|l|l|}
\hline Level of Readiness & Frequency & $\%$ \\
\hline Fully ready & 121 & 50.4 \\
\hline Just ready & 95 & 39.6 \\
\hline Not ready & 18 & 7.5 \\
\hline Don't want to use at all & 5 & 2.1 \\
\hline No response & 1 & 0.4 \\
\hline Total & 240 & 100 \\
\hline
\end{tabular}

It is shown on table 3 that $50.4 \%$ of the social science pre-service teachers were fully ready for podcasting, $39.6 \%$ were just ready, $7.5 \%$ were not ready while $2.1 \%$ do not want to use podcast at all.

\section{Hypothesis Testing}

Hypothesis 1: There is no significant difference in level of readiness of podcasting as a learning support tool between male and female social science pre-service teachers.

Table 4: t-test of pre-service teacher's readiness for podcasting by Gender.

\begin{tabular}{|c|c|c|c|c|c|c|c|c|}
\hline Gender & $\mathrm{N}$ & Mean & Std Dev. & Std Error & $\mathrm{t}$ & Df & $\mathrm{p}$ & Remark \\
\hline Male & 105 & 28.35 & 5.798 & .566 & \multirow[t]{2}{*}{-0.168} & \multirow[t]{2}{*}{238} & \multirow[t]{2}{*}{.867} & \multirow[t]{2}{*}{ Ns } \\
\hline Female & 135 & 28.47 & 5.382 & .463 & & & & \\
\hline
\end{tabular}

NS $=$ Not Significant at $\mathrm{P}<0.05$

From table 4, the male pre-service teacher's readiness mean score was 28.35 while the female preservice teacher had 28.47 which is slightly higher than that of the male teachers. The table also reveals that the difference in readiness between male and female pre-service teacher was not significant $(\mathrm{t}(238)=-.168, \mathrm{P}>$ 0.005). The hypothesis that there is no significant difference in level of readiness of podcasting as a learning support tool between male and female pre-service teacher was not rejected. It shows both are equally ready.

Hypothesis 2: There is no significant difference in the level of readiness for podcasting as a learning support tool based on age levels of social science pre-service teachers.

Table 5: Descriptive and ANOVA of Pre-service Teachers' level of Readiness for Podcasting by age.

\begin{tabular}{|c|c|c|c|c|c|c|c|c|c|}
\hline Age & $\mathrm{N}$ & Mean & Std. Dev & Source & $\begin{array}{l}\text { Sum of } \\
\text { Squares }\end{array}$ & Df & $\begin{array}{l}\text { Mean } \\
\text { Square }\end{array}$ & $\mathrm{F}$ & $\mathrm{P}$ \\
\hline $15-20$ & 86 & 28.41 & 5.521 & \multirow{2}{*}{$\begin{array}{l}\text { Between } \\
\text { Groups }\end{array}$} & \multirow[t]{2}{*}{35.220} & \multirow[t]{2}{*}{3} & \multirow[t]{2}{*}{11.740} & \multirow{6}{*}{.377} & \multirow{6}{*}{$.769 \mathrm{~ns}$} \\
\hline $21-25$ & 113 & 28.42 & 5.532 & & & & & & \\
\hline & & & & \multirow{3}{*}{$\begin{array}{l}\text { Within } \\
\text { Groups }\end{array}$} & \multirow[t]{3}{*}{7343.276} & \multirow[t]{3}{*}{236} & \multirow[t]{3}{*}{31.116} & & \\
\hline & & & & & & & & & \\
\hline $26-30$ & 30 & 29.00 & 6.125 & & & & & & \\
\hline $\begin{array}{l}31 \text { and } \\
\text { above }\end{array}$ & 11 & 26.91 & 4.867 & Total & 7378.496 & 239 & & & \\
\hline
\end{tabular}

$\mathrm{NS}=$ Not Significant at $\mathrm{P}<0.05$

Table 5 reveals that pre-service teachers of ages 26-30 years had the highest level of readiness for podcasting $(X=29.00)$ followed by those with ages $21-25$ years $(X=28.42)$ and $15-20$ years $(X=28.41)$ followed subsequently. Teachers that had least level of readiness are those with ages 31 years and above. ANOVA results also shows that the difference in the level of readiness for podcast of pre-service teachers based on their ages was not significant $(\mathrm{f}(3.236)=.377, \mathrm{P}>0.05)$. Therefore hypothesis 2 was not rejected. 
Hypothesis 3: There is no significant difference in the level of readiness for podcasting based on social science pre-service teachers' teaching subjects.

Table 6: Descriptive and ANOVA of pre-service teachers' level of readiness for podcasting by Teaching Subjects.

\begin{tabular}{|c|c|c|c|c|c|c|c|c|c|}
\hline $\begin{array}{l}\text { Teaching } \\
\text { Subjects }\end{array}$ & $\mathrm{N}$ & Mean & Std. Dev & Source & $\begin{array}{ll}\text { Sum of } \\
\text { Squares }\end{array}$ & Df & $\begin{array}{l}\text { Mean } \\
\text { Square }\end{array}$ & $\bar{F}$ & $\mathrm{p}$ \\
\hline ECO & 78 & 28.45 & 5.462 & \multirow{2}{*}{$\begin{array}{l}\text { Between } \\
\text { Groups }\end{array}$} & \multirow[t]{2}{*}{32.819} & \multirow[t]{2}{*}{5} & \multirow[t]{2}{*}{6.564} & \multirow{6}{*}{.209} & \multirow{6}{*}{$.958 \mathrm{~ns}$} \\
\hline GEO & 19 & 29.37 & 5.698 & & & & & & \\
\hline & & & & \multirow{2}{*}{$\begin{array}{l}\text { Within } \\
\text { Groups }\end{array}$} & \multirow[t]{2}{*}{7345.677} & \multirow[t]{2}{*}{234} & \multirow[t]{2}{*}{31.392} & & \\
\hline POS & 122 & 28.32 & 5.604 & & & & & & \\
\hline RES & 12 & 28.00 & 6.223 & \multirow{2}{*}{ Total } & \multirow[t]{2}{*}{7378.496} & \multirow[t]{2}{*}{239} & & & \\
\hline OTHERS & 7 & 28.71 & 5.589 & & & & & & \\
\hline
\end{tabular}

$\mathrm{NS}=$ Not Significant at $\mathrm{P}<0.05$

From table 6, the mean level of readiness for podcasting of Geography pre-service teachers was highest with 29.37 and followed by the Economics pre-service teachers (28.45), Political Science teachers (28.32) and religious Studies teachers (28.00) in that order. History pre-service teachers had the least level of readiness $(X=26.00)$ and other teaching subjects teachers had 28.71. ANOVA result on the table also shows that the difference in the level of readiness for podcasting based on teachers' teaching subjects was not significant (f $(5.234)=.209, \mathrm{P}>0.05)$. Therefore Hypothesis 3 is not rejected.

\section{Discussion Of Finding}

The essence of education is to find ways to best improve learning and teaching methods for tomorrow's workforce. With the rapid pace of growing globalization and foreign competition, it is imperative that modern day educators embrace new technologies as a method to align their teaching skills with the expectations of a "wired" generation. Podcasting can be one of the innovations used to help fill these needs.

There are many concerns and perceptions of new innovations that can affect the adoption of new training and delivery tools. Students can have different levels of comfort, technical skills, interests, needs, abilities when learning new skills or accepting a new medium. Readiness can also have an impact on the acceptance and use of new technologies.

It is deduced from the study, that mobile phones $(89.6 \%)$ are the most available technological gadget for podcasting among the pre-service teachers. This can be alluded to the fact that mobile phones are currently an integral part of everyday life for most people, it is used frequently and people keep them turned on for extended period of time. Mobile phone usage among students has increased rapidly because the mobile phone also serves as a mobile entertainment for them where they can play music, video, download games and browse. This supports the finding of Moore and Rutter (2003) that any leisure activity undertaken via a personal technology which is, or has the potential to be, networked and facilities transfer of data (including voice, sound and images) over geographic distance either on the move or at the variety of discrete locations is mobile entertainment. Williams \& Fardon(2007) opined that in 2001, mp3 functionality began to appear on mobile phones and in 2005 all major handset makers had released music phones and by 2006, more mp3 players were sold in mobile phones than all standalone mp3 put together. However, Evan \& Fan, (2002) stated several suitable devices which could be used to download and listen to podcast. The devices includes digital media players (e.g. IPod, MP3 player), smartphone (e.g. Blackberry, IPhones) mobile phones (MP3 enabled), and Personal Digital Assistants or PDAs (e.g. Palm, Pocket PC). The reason for the large possession of mobile phone may lie in the fact that the technology provide many opportunities for widening participation and enable easier access to learning, also, the mobile phones are more reasonably priced than desktop computers, IPod, and therefore present a less expensive method of accessing a myriad of tools all in one small device.

Furthermore, majority of the pre-service teachers are ready for podcasting. The readiness findings reveal that students are ready for educational podcasting. If mobile learning is an important mode of learning for students, educators must begin to introduce not only digital media players, but also the association of using these devices for educational purposes and the technology of podcasting in general. A finding consistent with this is by Campbell (2005) who stated that today's students increasingly expect technology-rich learning environments and experiences

The Relationship Between The Demographic Variables And Level Of Readiness Of Pre-Service Teachers To The Use Of Podcasting As A Learning Tool.

Gender: Gender differences in the level of readiness on the use of podcasting as a learning support tool was a demographic variable of interest in this study. $T$-tests used to analyze the mean difference showed that there is 
no difference between male and female in the level of readiness for the use of podcasting $(t=-0.168, \mathrm{~d} f=238$, $\mathrm{p}=.867$ ). Based on the result, the finding agrees with Hurley and Vosburg (1997), Kaino and Salani (2004), and Kay (2006) that there is no significant difference between female and male students' readiness towards the use of technology. Both male and female students were moderately willing to using the technology for their learning experiences. In a recent study, Dabaj (2009) reports that female students have better perceptions of distance education compared to male students. By its nature, distance education involves technology adaptation to the instruction. Then, although female students may limit themselves in finding out emerging technologies and its use, they still have a good mental adaptation to utilize technology for learning.

Age: From the study, finding shows that there is no significant difference in readiness for podcast use based on the age level of pre-service teachers. The age range of students who participated in the study is 15-20 years, 2125years, 26-30 years and 31 years above. It can also be noted that we are in the digital age and the younger people tends to be more technology savvy than the older people. Users' readiness depends on the age grade. This is in support of Ling (2003) and Faulkner and Culwin (2005) that stated that majority of their subjects between the ages 15 and 30 are aware of the technology advances around them and would like use them more often. Besides, younger people appear to have higher levels of self-worth than older people, and thus tend to decide for themselves whether to adopt an advanced m-learning system without being influenced by those around them, Ling (2003). Though a number of studies of technology usage and age have found that usage diminishes with age, and sometimes this is linked with attitudes towards specific technologies like the Internet (Pew-Internet 2001, US Department of Commerce 2002). The Department of Commerce study found that computer and Internet use is highest among teens and young adults, while people over 50 years old are less likely to use computers.

The younger adult, have the capability of learning new things faster compared to the older generations, regardless of their gender. This explains as to why the difference is not pronounced between the males and females.

Teaching Subjects: It is important for this study to determine if the teaching subjects offered by students affect their level of readiness to the use of podcasting. There are several teaching subject but the ones that participated in this study are Economics, Geography, Political Science, Religious Studies, and History. Based on the result in this study, it has been deduced that the teaching subject of pre-service teachers have no effect on their readiness on the use of podcast as a support tool. Researchers have recommended that technology should be integrated throughout the curriculum in order to provide pre-service teachers with the experiences needed to apply technology to their specific content areas (Kirschner \& Selinger 2003; Ottenbreit-Leftwich 2010). The result therefore does not agree with Alampay, 2006 \& Campbell, 2005 who stated that there is a difference in terms of department in addressing the digital divide. It however further support a research on TPACK (Koehler \& Mishra, 2009) who suggested that teachers need to develop technological pedagogical content knowledge (TPACK) in order to be successful user of technology in their teaching subjects. Also, data from this study, suggest that pre-service teachers have a positive attitude towards the use of podcast. Given the relative newness of podcast technology, it is surprising the level of interest of pre-service teachers. Recent studies have seen podcasting to offers innovative ways to support teaching and learning, and impacts all areas of education from distance learning to K-12 education to adult learning. The pedagogical use of podcasting is into areas of lecturing, tutoring, and remediation (Morales \& Moses, 2006). Podcasting is used in education to provide recording of lectures, class discussions, instructor feedback, dissemination of course content, sports events distribution, field recording, study support, interview and lots more. Also, it offers the advantages that students have the flexibility to learn anywhere and anytime it is convenient to them thereby providing with a flexible self-paced learning experience and addressing students with different learning styles. Podcasting helps students to do more fieldwork, provide audio feedback to peers, and reduce dependence on multimedia labs or library locations and hours (Belanger, 2005). Podcasting helps in revising large amount of content easily and quickly by listening to key concepts again. Podcasting helps students who find listening and visualization better than reading. Effective use of podcasting helps promotes increased students engagement and interest in classroom discussions, labs, field research, and independent projects.

\section{Conclusion}

The benefits associated with podcasting, along with its cost-effectiveness, make it an ideal medium for producing material to address students' preconceptions about a subject and its content, and to alleviate the anxiety that students bring into the classroom. With the proliferation of portable technologies devices such as mobile phones, Mp3, ipod, it has opened up exciting new possibilities for mobile learning (m-learning). Podcasting has however become a major feature of contemporary society and has emerged as a means for supporting learning within educational institutions. As the educational needs and wants of the student continue to change, it is the responsibility of educators to meet the desires and expectations of students. Podcasting will provide an easy, effective and economical way to reach students beyond the classroom walls. The authors of this 
paper have been able to determine that gender, age and teaching subjects have no significant difference on readiness of pre-service teacher to the use of podcast. It further shows that students are ready to make use of podcast if only it's introduced to them. Since the essence of education is engaging students and making connections, it is the essential for educators to effectively integrate podcast into the instructional process.

\section{References}

[1] Evans, C., Fan, J. 2002. Lifelong learning through the virtual university. Journal of Campus Wide Information Systems, 19(4), 127134

[2] Evans, C. 2007. The effectiveness of m-learning in the form of podcast revision lectures in higher education. Computers \& Education, 50, 491-498. doi:10.1016/j.compedu.2007.09.016

[3] Walton, G., Childs, S., Blenkinsopp, E. 2005. Using mobile technologies to give health students access to learning resources in the UK community setting. Health Information and Libraries Journal, 22 (2), 51-65.

[4] Campbell 2005. There is something in the air: podcasting in education. EDUCASE Review, vol. 40, no. 6 (Nov/dec 2005): 32-47. http://www.educause.edu/apps/er/erm05/erm0561.asp

[5] Udell, j. "Hypermedia: Why Now?" O’Reilly Network, March 18. www.oreillynet.com/pub/a/network/2011/03/18/primetime. html

[6] Educause. 2005. 7 things you should know about podcasting. Educause Learning Initiative. Retrieved April 15, 2011, from http://www.educause.edu/ir/library/pdf/ELI7003.pdf

[7] Chan, A., \& Lee, M. 2005. An MP3 a day keeps the worries away: Exploring the use of podcasting to address preconceptions and alleviate pre-class anxiety amongst undergraduate information technology students. In D. Spennemann \& L. Burr (Eds.), Good Practice in Practice: Proceedings of the Student Experience Conference (pp. 59-71). Wagga Wagga, NSW, Australia: Charles Sturt University

[8] Prensky, M. 2007. How to teach with technology: Keeping both teachers and students comfortable in an era of exponential change. Emerging Technologies for Learning, Vol. 2 (2007). [viewed 3 June 2012].

[9] Moore, k. \& Rutter, J. 2003 'Defining Mobile Entertainment' in mGain, Mobile entertainment State-of -the Art, available at http://www.mgain.org/MGAIN-wp3-d311-revised-final pdf (Accessed July 2012)

[10] Williams, J., and Fardon, M. 2007. Perceptual connectivity: Lecture recordings and portable media players. In ICT: Providing choices for learners and learning. Proceedings ascilite Singapore 2007. http://www.ascilite.org.au/conferences/singapore07/procs/williams-jo.pdf

[11] Hurley, N.P. and Vosburg, J.D. 1997. Modern Technology: the relationship between student attitudes towards learning using modern technology in an everyday setting. (ERIC Document Reproduction Service No. ED 386171).

[12] kaino, L.M and Salani, E.B. 2004. Students' Gender Attitude Towards the Use of Calculators in Mathematics Instruction. International Group for the Psychology of Mathematics Education.

[13] Kay, R. H. 2006. Evaluating Strategies Used To Incorporate Technology Into Preservice Education: A Review Of the Literature. Journal of Research on Technology in Education, 38 (4), 383-408.

[14] Dabaj, F. 2009. The role of Gender and Age on Student's Perception towards online education. Case study: Sakarya University, Vocational High School. The Turkish Online Journal of Educational Technology. Volume 8, issue 2, Pages 120-123

[15] Ling, R., 2003, The Socio-linguistic of SMS: An Analysis of SMS Use by a Random Sample of Norwegians. In Mobile Communications: Renegotiation of the Social Sphere, Ling, R. and Pedersen, P. (Eds.), pp. 335 -349 (London: Springer, 2003).

[16] Faulkner, X. and Culwin, F., 2005, When Fingers Do The Talking: A Study of Text Messaging. Interacting with Computers, 17, pp. $167-185$.

[17] Pew-Internet, 2001, Wired Seniors: A Fervent Few, Inspired by Family Ties. Available at: www.perinternet.org/reports/pdfs/PIP_Wired_Seniors_Report.pdf (accessed July 2012)

[18] Kirschner, P. and Selinger, M. 2003. The state of affairs of teacher education with respect to information and communications technology. Technology, Pedagogy and Education 12 (1), 5-17

[19] Ottenbreit-Leftwich, A. T., Glazewski, K. D., Newby, T. J., \& Ertmer, P. A. 2010. Teacher value beliefs associated with using technology: Addressing professional and student needs. Computers \& Education, 55 (3), 1321-1335

[20] Alampay, A. 2006. "Beyond access to ICTs: Measuring capabilities in the information society". In International journal of Education and Development using information and communication technology, August 10, 2 (3). http://ijedict.dec.uwl.edu/viewarticle.php?id=196

[21] Koehler, R., and Mishra, K. 2009: Alternative Content Distribution Channels for Mobile Devices. In: Hug, T., Lindner, M., Bruck, P.A. (Eds.), Micromedia \& e-Learning 2.0: Gaining the Big Picture. Proceedings of Microlearning Conference 2006, Innsbruck (Austria), pp. 119 - 130, Innsbruck University Press, 2006

[22] Morales C., and Moses J.S. 2006. Podcasting: Recording, managing and delivering the classroom experience. Retrieved from http://net.educause.edu/ir/library/pdf/dec0604.pdf

[23] Belanger, Y. 2005: Duke University iPod First Year Experience Final Evaluation Report. Retrieved June 30, 2011: from http://www.duke.edu/ddi/pdf/ipod_initiative_04_05.pdf 